\title{
Decolorization of Cibacron
}

\section{Yellow S-3R Using Coriolus Versicolor (MTCC 138)}

\author{
Sivakumar Venkatachalam (Corresponding author) \\ Department of Chemical Engineering, Kongu Engineering College \\ Perundurai, Erode - 638052, TN, India
}

Tel: 91-4294-226-602Ｅ-mail: drvsivakumar@yahoo.com

Chitradevi Venkatachalam

Department of Chemical Engineering, Kongu Engineering College

Perundurai, Erode - 638052, TN, India

Tel: 91-4294-226-602Ｅ-mail: erchitrasuresh@yahoo.com

\begin{abstract}
The aim of the present study is to analyze the ability of the white rot fungi Coriolus Versicolor (MTCC 138) in the decolorization of Cibacron Yellow S-3R, a recalcitrant azo reactive textile dye. The influencing parameters that affect the percentage of decolorization rates are optimized in batch mode. The optimal values of the parameters such as mycelia age, temperature, $\mathrm{pH}$, initial dye concentration and carbon source concentration are found to be 7 days, $30^{\circ} \mathrm{C}$, $5.4,100 \mathrm{mg} / \mathrm{l}$ and $2 \mathrm{mg} / \mathrm{l}$ respectively. The maximum percentage of decolorization at the optimized conditions is found to be $90 \%$. It is also conferred that there is substrate inhibition to fungal decolorization when initial dye concentration is greater than $100 \mathrm{mg} / \mathrm{l}$.
\end{abstract}

Keywords: Decolorization, Textile dye, White rot fungi, Percentage decolorization

\section{Introduction}

Textile dyeing industries is one of the fast growing, major export oriented industrial sectors in India. Dyeing, the fundamental unit operation during textile fiber processing, is gifted with large amounts of structurally diverse dyestuffs which are classified as azo dyes, anthraquinone dyes, phthalocyanine dyes etc., based on the chemical structure of the chromophoric group. Amongst them utilization of azo reactive dyes has been consistently increasing, as they provide ease of application, high wet fastness profiles, brilliant color shades and less energy consumption. These dyeing operations result in the production of more or less colored wastewaters (Rodrigues et al., 1999), depending on the degree of fixation of the dyestuffs on the substrates, which varies with the nature of the fabrics, the desired intensity of coloration, and the application method (Pearce et al., 2003). The presence of unfixed dyes in such waste waters is much higher than the allowable limits and extremely harmful to aquatic flora, fauna and human beings through food chains (Pierce, 1994). The textile dyeing process consumes large quantities of water and due to increasing global water scarcity, total or partially reuse of effluent after the necessary treatments becomes mandatory. Therefore, color removal criteria are more and more demanding attention. The conventional physical and chemical effluent treatment methods such as adsorption, chemical precipitation and flocculation are inefficient as they result either in large volumes of sludge or in the release of toxic substances (Spadaro et al., 1992). All the methods possess significant differences in color removal results, volume capability, operating time and capital costs. White rot fungi have been studied for their ability to degrade recalcitrant organo-pollutants such as polycyclic aromatic hydrocarbons (Bogan \& Lamar, 1996), chlorinated phenols (Ruckenstein \& Wang, 1994), PCBs (Sasek et al., 1993, Beaudette et al., 1998), dioxins (Takada et al., 1996), pesticides (Kullman \& Matsumura, 1996), explosives (Gorontzy et al., 1994), dichloroaniline (Arjmand \& Sandermann, 1985) and dyes (Kirby et al., 1995, Shin et al., 1997, Rodriguez et al., 1999). From the analysis of literature it is found that many authors used white rot fungi for decolorization of textile effluents (Chagas \& Durrant, 2001, Swamy \& Ramsay 1999, Yesilada et al., 2002, Kirby et al., 1995, Shin et al., 1997, Rodriguez et al., 1999, Wesenberg et al., 2003). 
Though the number of studies on the biodegradation of dyestuffs have been steadily increasing in recent years, very few researches are reported for biodegradation of azo dyes, such as Cibacron Yellow S-3R using white rot fungi (Yesilada et al., 1998) and hence in this present research an attempt has been made to investigate the biological decolorization of the azo dye Cibacron Yellow S-3R using Coriolus Versicolor (MTCC 138).

\section{Material and Methods}

The organism used for decolorization Coriolus Versicolor (MTCC 138) is purchased from the Microbial Type Culture Collection and Gene Bank, Institute of Microbial Technology, Chandigarh, India. The fungus is cultured at $30^{\circ} \mathrm{C}$ on slant Sabouraud's Dextrose Agar and after a week a conidial suspension is prepared and utilized for the cultivation of the inoculums. $5 \mathrm{ml}$ of the suspension is transferred to $250 \mathrm{ml}$ flask containing $100 \mathrm{ml}$ Sabouraud's Dextrose Broth. It is incubated at $30^{\circ} \mathrm{C}$ for 5 days in a shaking incubator at $130 \mathrm{rpm}$.

Batch experiments are performed in 250 flasks containing fresh SDB (2 ml homogenate / $100 \mathrm{ml}$ SDB $)$ along with desired concentration of dye (Yesilada et al., 2002). The contents of the flasks are sterilized for $20 \mathrm{~min}\left(1.5 \mathrm{~atm}, 121^{\circ} \mathrm{C}\right)$ and incubated in shaking incubator at $130 \mathrm{rpm}$. Samples are collected for every time interval and they are centrifuged at $1200 \mathrm{rpm}, 20 \mathrm{~min}$ and supernatant is used for analysis. Absorbance measurements are done at maximum absorbance $\left(\lambda_{\max }=472 \mathrm{~nm}\right)$ of dye using UV-Visible Spectrophotometer 119. Percentage decolorization efficiency is calculated according to the following formulation:

Percentage of Decolorization $=\frac{A_{b}-A_{a}}{A_{b}}$

Where $A_{b}$ is the absorbance at the maximum absorption wavelength of dye before decolorization and $A_{a}$ is the absorbance at the maximum absorption wavelength of dye after decolorization

\section{Results and Discussion}

\subsection{Effect of mycelia age}

The effect of mycelia age on percentage of decolorization is studied using different days of culture growth, namely 5 days, 7 days 8 days and 9 days. From the results shown in Figure 1, it is found that 5 days of growth culture requires 48 hours to achieve maximum decolorization, whereas 7 days of growth culture takes only 24 hours for decolorization. Further increasing days of culture growth doesn't make any appreciable change in the percentage of decolorization and hence 7 days of culture growth is found to be optimum for further studies. The same trend is also observed by Duygu et al., (2005) for bio decolorization of Brilliant Blue using Funalia trogii

\subsection{Effect of carbon source concentration}

Addition of a carbon source such as glucose at different concentrations has an effect on the percentage of decolorization and it is shown in Figure 2. The concentration of glucose is varied from $0.5 \mathrm{mg} / 1$ to $5 \mathrm{mg} / \mathrm{l}$. From the analysis of Figure 2 it is found that the percentage of decolorization increases with the increase in concentration of glucose upto maximum glucose concentration of $2 \mathrm{mg} / \mathrm{l}$ and after which there is not much appreciable increase in percentage of decolorization (Swamy et al., 1999).

\subsection{Effect of temperature}

The operating temperature of the incubation process is varied between $20^{\circ} \mathrm{C}$ and $60^{\circ} \mathrm{C}$, to study the effect of temperature on the decolorization process that is shown in Figure 3. It clearly shows that at temperatures below $30^{\circ} \mathrm{C}$, the growth of the fungi was too slow, that it took more days for decolorization and at temperatures above $30^{\circ} \mathrm{C}$ the activity of Coriolus Versicolor (MTCC 138) is reduced and hence percentage of decolorization decreases. From the analysis of the results it is found that optimal temperature for decolorization occurs at $30^{\circ} \mathrm{C}$.

\subsection{Effect of $\mathrm{pH}$}

The effect of $\mathrm{pH}$ is studied by incubating the reaction mixtures with the $\mathrm{pH}$ varying from $3.5-7$. The fungus is able to decolorize the dye during the $\mathrm{pH}$ range of $4.5-7$ which is shown in Figure 4 . The optimum $\mathrm{pH}$ is found to be 5.5 at which the maximum decolorization has occurred. For $\mathrm{pH}$ values below 5.5 there is no appreciable growth of fungi and hence percentage of decolorization decreases. Increase in $\mathrm{pH}$ greater than 5.5 resulted in the fragmentation of mycelia pellets and hence percentage of decolorization decreases.

\subsection{Effect of initial dye concentration}

The effect of initial concentration of the dye is studied by varying the concentration from $50 \mathrm{mg} / 1$ to $300 \mathrm{mg} / 1$ with the optimal values of temperature, $\mathrm{pH}$ and glucose concentration at $30^{\circ} \mathrm{C}, 5.5$ and $2 \mathrm{mg} / 1$ respectively. The results show that in all initial dye concentrations, Coriolus Versicolor (MTCC 138) could effectively decolorize Cibacron Yellow dye. From the plot (Figure 5), it can be seen that though the percentage of decolorization increases with the initial dye concentrations and it reaches the maximum of 90 percentage of decolorization at $100 \mathrm{mg} / \mathrm{l}$ of initial concentration. There is a decrease in the percentage of decolorization for initial dye concentrations above $100 \mathrm{mg} / \mathrm{l}$, and it is mainly due 
to substrate inhibition.. (Al-Sabti, 2000, Chen, 2002, Gottlieb et al., 2003, Marlasca et al., 1998, Rosa et al., 2001, Walthall \& Stark, 1999, Yesilada et al., 2003, Yun \& Qi-xing, 2002).

\section{Conclusion}

From the study of decolorization of Cibacron Yellow S3-R by Coriolus Versicolor (MTCC 138), it is found that the optimal mycelia age is 7 days and optimal initial dye concentration is $100 \mathrm{mg} / \mathrm{l}$ and also the optimum temperature, $\mathrm{pH}$ and glucose concentration are found to be $30^{\circ} \mathrm{C}, 5.5$ and $2 \mathrm{mg} / \mathrm{l}$ respectively. The potential ability of fungi shows that it can be used for the biodegradation of textile effluents. This study has to be further improved for continuous treatment of textile effluents.

\section{References}

Al-Sabti, K. (2000). Chlorotriazine reactive azo Red 120 textile dye induces micronuclei in fish. Exotoxicol. Environ. Saf, 47, 149-155.

Arjmand, M., \& Sandermann, H. (1985). Mineralization of chloraniline/ lignin conjugates and of free chloranilines by white rot fungus Phanerochaete chrysosporium. J. Agric. Food Chem., 33, 1055-1060.

Beaudette, L. A., Davies, S., Fedorak, P. M., Ward, O. P., \& Pickard, M. A. (1998). Comparison of biodegradation and mineralization as methods for measuring loss of selected polychlorinated biphenyl congeners in cultures of four white rot fungi. Appl. Env. Microbiol, 64, 2020-2025.

Bogan, B. W., \& Lamar, R. T. (1996). Polycyclic aromatic hydrocarbon degradation capabilities of Phanerochaete leavis HHB-1625 and its extracellular ligninolytic enzymes. Appl. Env. Microbiol, 62, 1597-1603.

Chagas, E. P., \& Durrant, L. R. (2001). Decolorization of azo dyes by Phanerochaete chrysosporium and Pleurotus sajorcaju. Enzyme Microbial Technol, 29,473-477.

Chen, B. Y. (2002). Understanding decolorization characteristics of reactive azo dyes by Pseudomonas luteola toxicity and kinetics. Process Biochem, 38, 437-446.

Duygu, H., zsoy, O“., Ali, U“ nyayar., \& Ali Mazmanc, M. (2005). Decolourisation of reactive textile dyes Drimarene Blue X3LR and Remazol Brilliant Blue R by Funalia trogii ATCC 200800. Biodegradation, 16, 195-204.

Gorontzy, T., Drzyga, O., Kahl, M. W., Bruns-Nagel, D., Breitung, J., von Loew, E., \& Blotevogel, K. H. (1994). Microbial degradation of explosives and related compounds. Crit. Rev. Microbiol, 20, 265-284.

Gottlieb, A., Shaw, C., Smith, A., Wheatley, A., \& Forsythe, S. (2003). The toxicity of textile reactive azo dyes after hydrolysis and decolourisation. J. Biotechnol, 101, 49-56.

Kirby, N., McMullan, G., \& Marchant, R. (1995). Decolourisation of an artificial textile effuent by Phanerochaete chrysosporium. Biotechnol. Lett, 178, 761-764.

Kullman, S. W., \& Matsumura, F. (1996). Metabolic pathways utilized by Phanerochaete chrysosporium for degradation of cyclodiene pesticide Endosulfan. Appl. Environ. Microbiol, 62, 593-600

Marlasca, M. J., Sanpera, C., Riva, M. C., Sala, \& R., Crespo, S. (1998). Hepatic alterations and induction of micronuclei in rainbow trout (Oncorhynchus mykiss) exposed to a textile industry effluent. Histol. Histopathol, 13,703-712.

Pearce, C. I., Lloyd, J. R. \& Guthrie, J. T. (2003). The removal of colour from textile wastewater using whole bacterial cells: a review. Dyes and Pigments, 58, 179-196.

Pierce, J. (1994). Color in textile effluents: the origins of the problem. J. Soc. Dyers Colorists, 110, 131-134.

Rodrigues, E., Pickard, M. A., \& Vazquez-Duhalt, R. (1999). Industrial dye decolourisation by laccases from ligninolytic fungi. Curr. Microbiol, 38, 27-32.

Rosa, E. V. C., Simionatto, E. L., Sierra, M. M. D. S., Bertoli, S. L., \& Radetski, C. M. (2001). Toxicity-based criteria for the evaluation of textile wastewater treatment efficiency. Environ. Toxicol. Chem, 20, 839-845.

Ruckenstein, E., \& Wang, X. B. (1994). Production of lignin peroxidase by Phanerochaete chrysosporium immobilized on porous poly(styrene-divinylbenzene) carrier and its application to the degrading of 2-chlorophenol. Biotechnol Bioeng, 44, 79-86.

Spadaro, J. T., Gold, M. H., \& Renganathan, V. (1992), Degradation of azo dyes by the lignin-degrading fungus. Phanerochaete chrysosporium. Appl. Environ. Microbiol, 58, 2397-2410.

Swamy, J., \& Ramsay, J., (1999). The evaluation of white rot fungi in the decoloration of textile dyes. Enzyme Microb. Technol, 24, 130-137. 
Sasek, V., Volfova, O., Erbanova, P., Vyas, B. R. M., \& Matucha, M. (1993). Degradation of PCBs by white rot fungi, methylotrophic and hydrocarbon utilizing yeasts and bacteria. Biotechnol. Lett, 15, 521-526.

Shin, K. S., Oh, I. K., \& Kim, C. J. (1997). Production and purification of Remazol Brilliant Blue R decolorization peroxidase from the culture filtrate of Pleurotus ostreatus. Appl. Env. Microbiol, 63, 1744-1748.

Takada, S., Naksamura, M., Matsueda, T., Kondo, R., \& Sakai, K. (1996). Degradation of polychlorinated dibenzo-p-dioxins and polychlorinated dibenzofurans by the white rot fungus Phanerochaete sordida YK-624. Appl. Env. Microbiol, 62, 4323-4328.

Walthall, W. K., \& Strak, J. D. (1999). The acute and chronic toxicity in two xanthene dyes fluorescein sodium salt and phloxine B to Daphnia pulex. Environ. Pollut, 104, 207-215.

Wesenberg D, Kyriakides I, \& Agathos S. N. (2003). White-rot fungi and their enzymes for the treatment of industrial dye effluents. Biotechnol. Adv, 22, 161-187.

Yesilada O, \& Ozcan B (1998). Decolourisation of orange II with the crude culture filtrate of white rot fungus, Coriolus Versicolor. Tr.J.Biol, 22, 463-476.

Yesilada, O., Cing, S., \& Asma, D. (2002). Decolourisation of the textile dye Astrazon Red FBL by Funalia Trogii Pellets. Bioresource technology, 81, 155-157.

Yesilada, O., Asma, D., \& Cing, S. (2003). Decolorisation of textile dyes by fungal pellets. Process Biochem. 38, 933-938.

Yun, C., \& Qi-xing, Z. (2002). Ecological toxicity of Reactive X-3B Red dye and cadmium acting on wheat (Triticum aestivum). J. Environ. Sci, 14, 136-140.

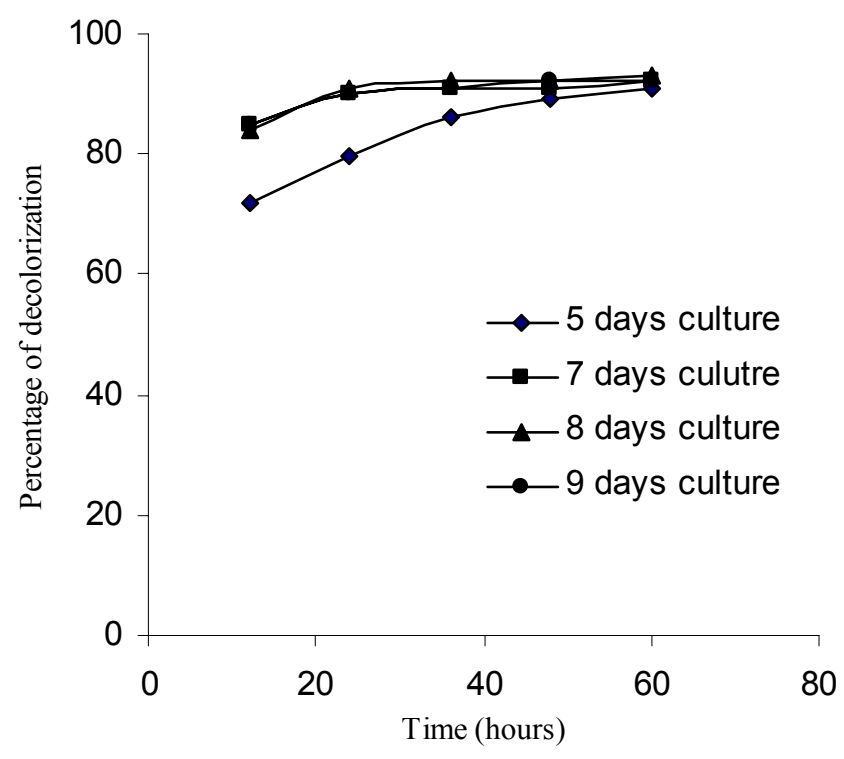

Figure 1. Effect of mycelia age on percentage of decolorization 


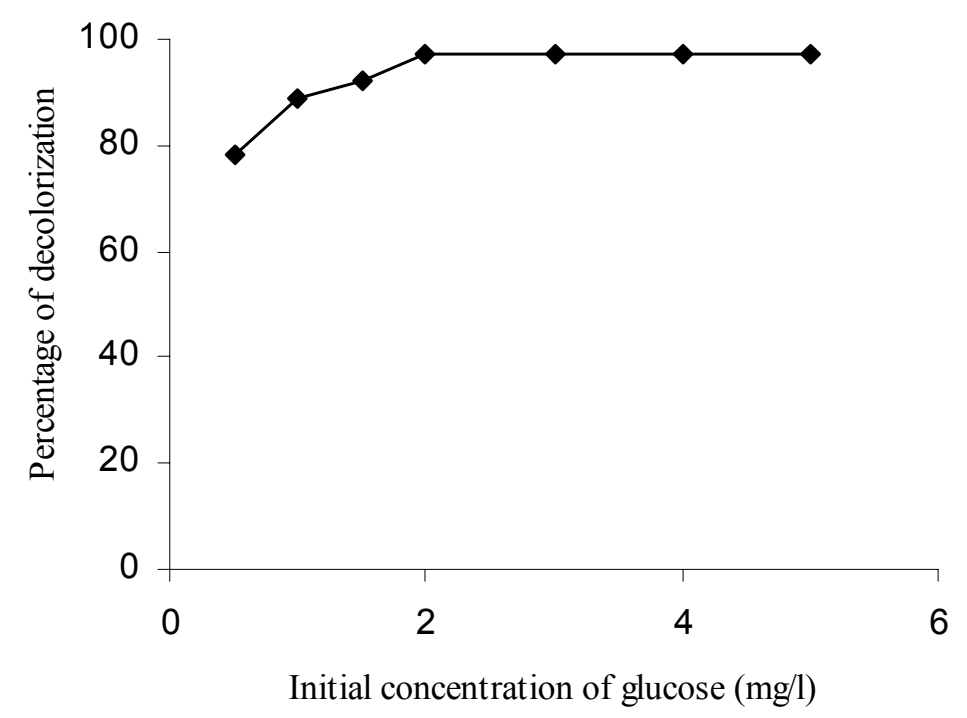

Figure 2. Effect of initial concentration of glucose on percentage of decolorization

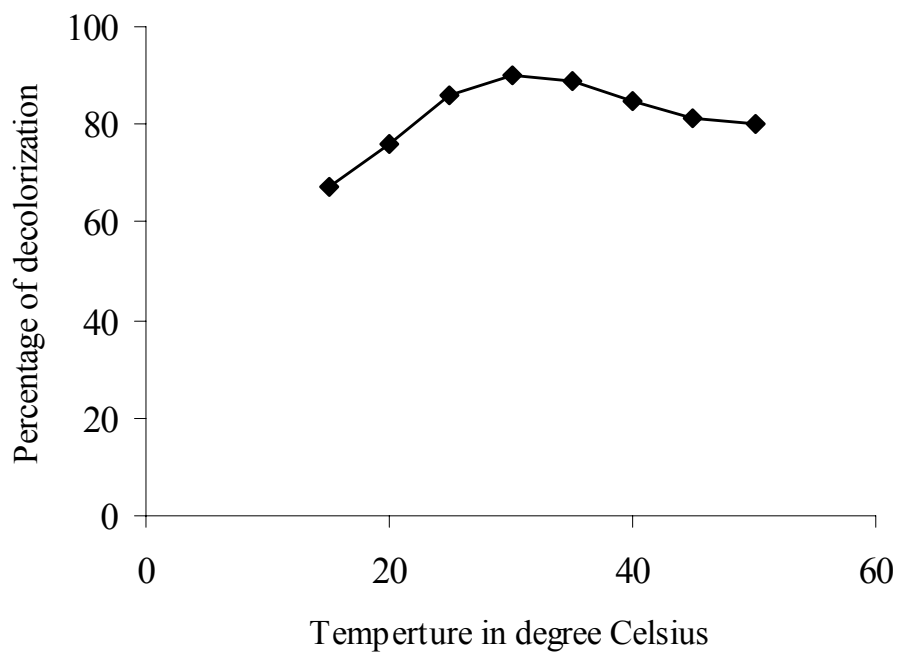

Figure 3. Effect of temperature on percentage of decolorization 


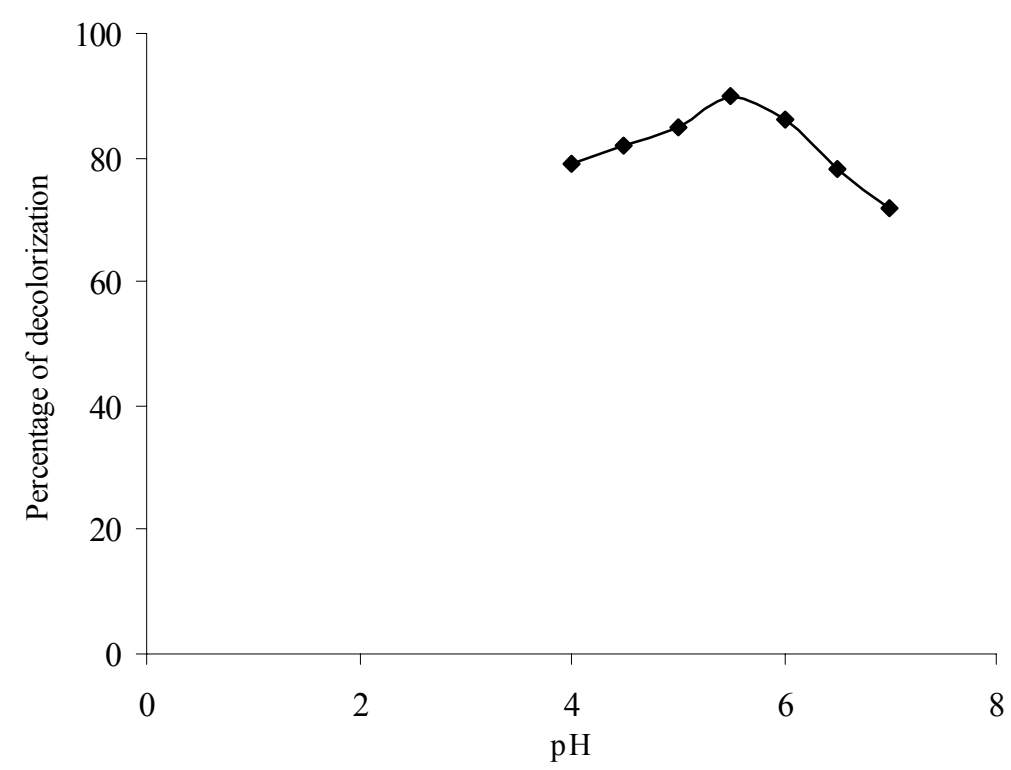

Figure 4. Effect of $\mathrm{pH}$ on percentage of decolorization

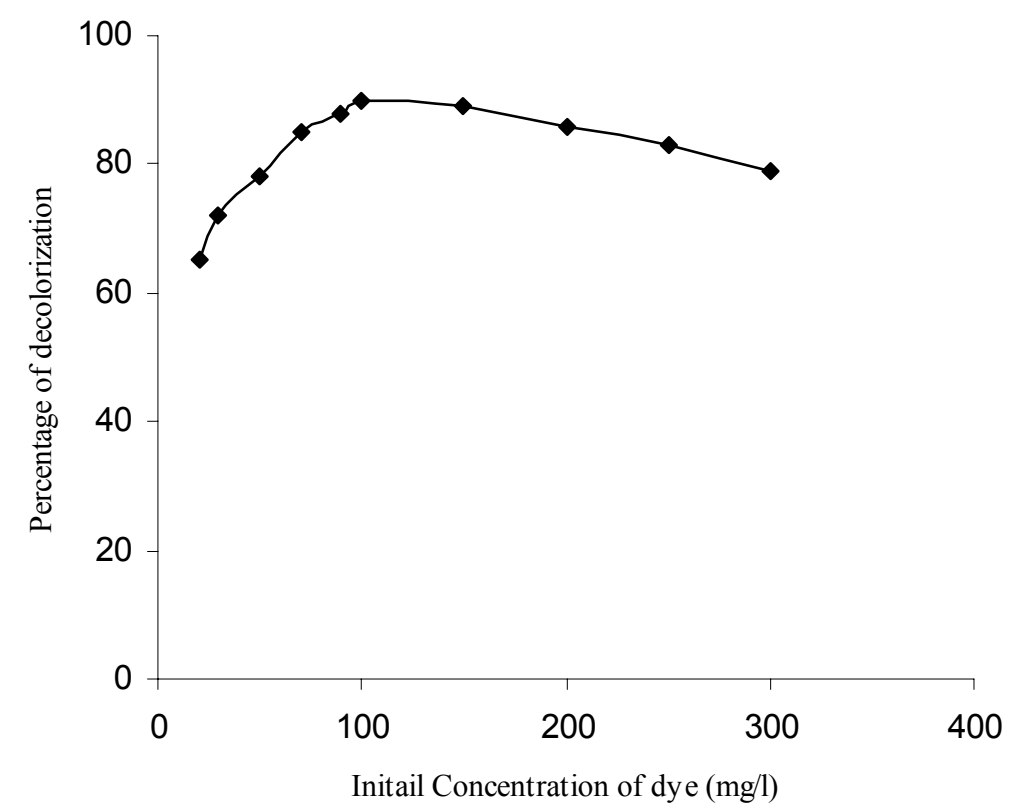

Figure 5. Effect of initial concentration of dye on percentage of decolorization 